\title{
Philipp Schweighauser \\ Sympathy Control: Sentimental Politics and Early European Aesthetics
}

\begin{abstract}
This essay re-reads early American sentimental novels (Charlotte Temple, The Coquette, Emily Hamilton) through the lens of contemporaneous European aesthetics (Baumgarten, Schiller) to argue that American writers' anxieties concerning the power of their work to either educate or deceive are more than defensive responses to the novel's detractors. These anxieties are real: they testify to concerns about the reliability of sensuous perception that also haunt early European aestheticians. Once we realize this, we see that sentimental writers do not, as major theorists of sentimentalism claim, unconditionally affirm the expression of feelings. Instead, they advocate what I call sympathy control.
\end{abstract}

Philipp Schweighauser, Universität Basel

E-mail: ph.schweighauser@unibas.ch

In 2009, the University of Nebraska Press published Sukey Vickery's epistolary novel Emily Hamilton (1803) in its "Legacies of Nineteenth-Century American Women Writers" series. ${ }^{1}$ Edited and introduced by Scott Slawinski, the volume comes as a very welcome addition to the corpus of early American novels. In his introduction, Slawinski writes,

\footnotetext{
Vickery's writings ... reveal a deep commitment to a realistic view of the world and a realist aesthetic in her work. While this reaches its highest achievement in Emily Hamilton, one can see in her poetry an unflinching look at the world. ... In her elegies, there are no excessive calls for tears such as might be found in more sentimental poems. ${ }^{2}$
}

Slawinski takes his argument a decisive step further when he contends that the recovery of Emily Hamilton may well prompt us to rewrite American literary history since Vickery's novel, which was published in 1803 and thus over half a century before realism begins in standard U.S. literary histories, is already characterized by a serious "commitment to a realist aesthetic". ${ }^{3}$ Slawinski then

1 Sukey Vickery, Emily Hamilton and Other Writings, ed. Scott Slawinski (1803; reprint, Lincoln: U of Nebraska P, 2009).

2 Scott Slawinski, "Introduction". Emily Hamilton and Other Writings, by Sukey Vickery, ed. Scott Slawinski (1803; reprint, Lincoln: U of Nebraska P, 2009) xxv.

3 Slawinski 2009, xxxvi. 
proceeds to a comparison of Emily Hamilton to Henry James' The Portrait of a Lady, concluding that "[e]ven William Dean Howells, the Dean of American Realism, might have appreciated Vickery's efforts, though perhaps not the final product". 4

Slawinski's claims deserve a closer look, for several reasons. First of all, pace Slawinski's (however cautious) comparisons of Emily Hamilton to texts by major realist writers, Vickery's novel displays neither the deft colloquialism of Mark Twain's The Adventures of Huckleberry Finn; nor the descriptive detail of Sarah Orne Jewett's regionalist short stories; nor the psychological realism of Henry James' prose; nor William Dean Howells' dissection of middle-class anxieties; nor Dreiser's hard-hitting social realism. Some of the differences are due to Emily Hamilton's epistolary form, but in the final analysis, Vickery simply has not written a realist text - neither in terms of style nor subject matter.

In fact, Emily Hamilton is in most respects a perfectly conventional sentimental novel. Apart from the keepsake motif, all major elements of the sentimental mode are present: the centrality of courtship, marriage, and female friendship; the sanctity of affective relationships, especially the mother-daughter bond; an abundance of teary scenes; characters' moral lecturing; a seduction plot; the ideal of love marriage; the allegorical mode; encomiums of pastoral life, domesticity, and charity; and deathbed scenes that fit in with sentimentalism's exceptionally strong concern with human finitude. In short, Emily Hamilton is as sentimental a novel as it gets.

Yet Slawinski does make a valid point when he writes that while Emily $\mathrm{Ha}$ milton contains emotionally charged and tearful scenes, Vickery's readers are also "presented with young women who meet [emotional] challenges rationally and effectively rather than with overflowing and sustained grief". ${ }^{5}$ The eponymous protagonist is especially adept at keeping her emotions in check. When Emily fears for the life of ailing Edward Belmont, an unhappily married man whose love for her she cannot reciprocate for fear of public disgrace, she hides her anguish when in company, "wear[ing] the smile of satisfaction on [her] countenance" as she "disguise[s]" her "real sentiments". 6 The earlier Letter XXXV, which Emily writes to her friend Mary Gray, presents a veritable case study of one woman's strenuous efforts to rein in her feelings and her passion. When she discovers that the man whom she fell in love with when he saved her from drowning is a married man, her romantic fantasies are cut short. She faints and is deeply distraught when she comes to her senses again. Yet just as

\footnotetext{
4 Slawinski 2009, xliii.

5 Slawinski 2009, xliii.

6 Vickery, Emily Hamilton, 100-101.
} 
quickly, she forms a resolution: "To see him before I had acquired strength or reason to conceal those emotions the sight of him had occasioned, I could by no means bear to think of". ${ }^{7}$ Intent on "disguis[ing] the real sentiments of [her] heart" should she see him again, Emily resolves to restrain her emotions and desires even more forcefully: "I determined if possible to extricate myself from a passion, which could only be productive of guilt and wretchedness, if it were indulged". ${ }^{8}$ In responding to Emily, Mary encourages her to stay the course of self-restraint: "You are endeavoring to overcome affection by reason, and you will undoubtedly succeed in time; but remember, my dear girl, matters of importance, are not often executed in a day". 9

On the face of it, Emily's resolution and her friend's advice fit squarely into the moral universe of sentimental fiction, where pre-marital dalliances spell doom for heroines. However, the two women's forceful conviction that untimely passions and emotions, including Emily's sympathy for the ailing Belmont, must be concealed immediately and suppressed by exertions of reason in due course must strike those acquainted with scholarship on sentimentalism since Jane Tompkins' Sensational Designs: The Cultural Work of American Fiction, 1790-1860 (1985) as running counter to some of the revisionist critics' most deeply held convictions about sentimental fiction. ${ }^{10}$ Our two characters' insistence on the need for emotional self-restraint does not sit easily with these scholars' argument that the cultural work sentimental novels do crucially depends on their valorization of openly expressed emotions. After all, one of the proclaimed aims of revisionist scholarship is to reverse the judgments implied by dictionary definitions of 'sentimentalism' as "the disposition to attribute undue importance to sentimental considerations, or to be governed by sentiment in opposition to reason; the tendency to excessive indulgence in or insincere display of sentiment”. ${ }^{11}$ As Tompkins, Judith Fetterley, Cathy N. Davidson, Joanne Dobson, Shirley Samuels, and others have argued, sentimentalism's emotional appeals have a political valence. ${ }^{12}$ Far from merely pandering to their readers' affective needs, sentimental writers highlight the tearful anguish of innocent

7 Vickery, Emily Hamilton, 82.

8 Vickery, Emily Hamilton, 82.

9 Vickery, Emily Hamilton, 85.

10 Jane Tompkins, Sensational Designs: The Cultural Work of American Fiction, 1790-1860 (Oxford: Oxford UP, 1985).

11 Oxford English Dictionary, 2nd ed., s.v. 'sentimentalism'.

12 See Tompkins, Sensational Designs; Judith Fetterley, “Introduction”. Provisions: A Reader from $19^{\text {th }}$-Century American Women, ed. J. Fetterley (Bloomington: Indiana UP, 1985) 1-40; Cathy N. Davidson, Revolution and the Word: The Rise of the Novel in America, 2nd exp. ed. (Oxford: Oxford UP, 2003); Joanne Dobson, "Reclaiming Sentimental Literature", American Literature 69.2 
characters for the purpose of cultural critique. By establishing strong emotional bonds between readers and characters that suffer at the hands of the dominant culture, they elicit our sympathy for socially marginalized groups and our moral outrage at their plight: that of unmarried women in Hannah Webster Foster's The Coquette (1797); that of displaced Native Americans in Lydia Huntley Sigourney's poem "The Cherokee Mother" (1831); and that of African-American slaves in the case of Harriet Beecher Stowe's Uncle Tom's Cabin (1852). ${ }^{13}$

For Slawinski, it is primarily Vickery's refusal to let her characters give unrestrained expression to their emotions that testifies to Emily Hamilton's renunciation of sentimentalism and its "carefully planned realism": 14

Once Emily unwittingly falls in love with a married man, a significant portion of the novel is dedicated to the illustration of her struggle to overcome her emotions rather than to the exploration of following the dictates of passion blindly - a significant break with other, more popular novels of the period. Structuring her book around this conflict allows Vickery to display her inner mental and emotional strength, ultimately developing an early strain of psychological realism that matured in novels by antebellum women and Nathaniel Hawthorne as well as in those by Henry James. ${ }^{15}$

Citing Davidson and Fetterley, Slawinski refers to revisionist scholarship on sentimentalism even as his determination to 'rescue' Emily Hamilton from being pigeon-holed as a sentimental novel reveals that his judgment of sentimentalism is ultimately more in accord with dictionary definitions of the term. While I cannot see why creating a literary character who struggles "to overcome her emotions" should by necessity be more realistic, let alone more realist, than creating one who "follow[s] the dictates of passion blindly", it is clear that Slawinski considers Emily Hamilton a (proto-)realist novel because it disavows what he considers the emotional excesses of sentimentalism.

I am less concerned with Slawinski's negative appraisal of the sentimental (here I side with revisionist scholarship). The point I wish to make is that a writer's decision not to let her characters give full expression to their emotional states makes a novel neither more realist nor less sentimental. In point of fact, what Slawinski observes is by no means a deviation from sentimental formulae. In classic works of U.S. sentimental fiction such as William Hill Brown's The

(1997): 263-88; and Shirley Samuels, The Culture of Sentiment: Race, Gender, and Sentimentality in Nineteenth-Century America (New York: Oxford UP, 1992).

13 Hannah Webster Foster, The Coquette (1797; reprint, Oxford: Oxford UP, 1987); Lydia Huntley Sigourney, "The Cherokee Mother", Nineteenth-Century American Women Poets: An Anthology, ed. Paula Bernat Bennet (1831; reprint, Oxford: Blackwell, 1998) 7-8; and Harriet Beecher Stowe, Uncle Tom's Cabin; or, Life Among the Lowly (1852; reprint, Oxford: Oxford UP, 2002).

14 Slawinski 2009, xxxv.

15 Slawinski 2009, xli. 
Power of Sympathy, Susanna Rowson's Charlotte Temple, and Foster's The Coquette, narrators, characters, and implied authors alike regularly suggest that unrestrained indulgence in fellow-feeling is harmful and must be checked by the power of reason. ${ }^{16}$ What I call sympathy control is an integral part of the sentimental tradition.

In Rowson's novel, Charlotte Temple's mother forms a remarkable resolution when she learns of her daughter's elopement. Stricken with grief, she determines to smile in the face of adversity:

I will endeavour to appear more cheerful, and by appearing in some measure to have conquered my own sorrow, alleviate the sufferings of my husband, and rouse him from that torpor into which this misfortune has plunged him. My father too demands my care and attention: I must not, by a selfish indulgence of my own grief, forget the interest those two dear objects take in my happiness or misery: I will wear a smile on my face, though the thorn rankles in my heart .... ${ }^{17}$

Rowson's narrator explicitly sanctions and applauds the mother's decision to dissimulate her feelings: "Thus argued this excellent woman: and in the execution of so laudable a resolution we shall leave her". ${ }^{18}$ Near the ending of Foster's The Coquette, we encounter a similar case of sympathy control when Julia Granby, who has just learned that her friend Eliza Wharton was debauched by Major Sanford, does her best to conceal her anguish over Eliza's despair when talking to her friend's mother: "I was obliged studiously to suppress even my thoughts concerning her, lest the emotions they excited might be observed". ${ }^{19}$ Perhaps, such paeans to sympathy control appear less out of sync with sentimentalism's strong emotional appeals when we remind ourselves that The Power of Sympathy, the title of the text that is generally considered the first American sentimental novel, most immediately refers to two siblings' near-incestuous desire for one another. Neither this novel nor those that follow it advocate any unconditional surrender to the power of sympathy.

In all these novels, character's decisions to rein in their sympathy for the suffering of others are well motivated on the diegetic level. The eponymous heroine of Emily Hamilton seeks to control her passion for Belmont and hide her distress over his ill health (and thus also her sympathy in its full etymological

16 William Hill Brown, The Power of Sympathy, in The Power of Sympathy and The Coquette, ed. William S. Osborne (1789; reprint, Schenectady: New College \& UP, 1970); Susanna Rowson, Charlotte Temple, ed. Cathy N. Davidson (1791; reprint, New York: Oxford UP, 1987); and Foster, The Coquette.

17 Rowson, Charlotte Temple, 56.

18 Rowson, Charlotte Temple, 56-57.

19 Foster, The Coquette, 144. 
sense, i.e., her suffering with another) because she cannot publicly express her love for a married man. While Emily Hamilton's determination to check her emotions is largely dictated by social conventions, Charlotte Temple's mother's decision "to wear a smile on my face, though the thorn rankles in my heart" is motivated by a sense of responsibility toward fellow family members: she controls her sympathy for Charlotte out of sympathy for her father's and her husband's suffering. In The Coquette, Julia Granby's decision to conceal her anguish over 'ruined' Eliza appears to be motivated by a combination of societal and interpersonal concerns: she neither wants to expose her friend to the social consequences of her transgression, nor does she want to burden Eliza's mother with the knowledge of that transgression since this would, Julia fears, "break her widowed heart" (143).

In all three novels, then, there are good reasons why characters keep their feelings for others in check. And "reasons" is indeed the operative word, since sentimental writers regularly attribute their characters' decisions not to let themselves be carried away by their emotions to the dictates of reason. Thus, when Emily Hamilton despairs over Belmont's medical condition, she chides herself for her inability to exert full rational control over her inner turmoil: "I was once firm, I did not suffer my spirits to be depressed, but now, instead of endeavoring to overcome my sorrows by reason and reflection, I yield to its [sic] pressure and almost sink beneath it". ${ }^{20}$ When Charlotte Temple resolves to reject Montraville's entreaties to elope with him to the other side of the Atlantic and return to her parents instead (a resolution that she will soon break), Charlotte exults, "How shall I rejoice ... in this triumph of reason over inclination". ${ }^{21}$ In The Coquette, too, characters strive for the "triumph of reason over inclination". It is not only the temperate Rev. Boyer who "hope[s]" and "trust[s]" that he "ever shall be a reasonable creature; and not suffer [his] judgment to be misled by the operations of a blind passion". ${ }^{22}$ Mrs. Richman's advice to Eliza Wharton rests on the very same hierarchy between reason and feeling: " $O$ my cousin, beware of the delusions of fancy! Reason must be our guide, if we would expect durable happiness".23

Sympathy control by way of reason is an integral aspect of sentimental novels that both their detractors and, more central to my argument, their revisionist defenders ignore. Given this lacuna in current scholarship, standard revisionist accounts of sentimental writing as "premised on an emotional and philosophical

20 Vickery, Emily Hamilton, 100.

21 Rowson, Charlotte Temple, 47.

22 Foster, The Coquette, 17.

23 Foster, The Coquette, 51. 
ethos that celebrates human connection, both personal and communal, and acknowledges the shared devastation of affectional loss" need to be revisited to take account of the fact that the characters, narrators, and implied authors of sentimental writing regularly advocate not the full expression of inner states but 'reasonable' emotional restraint. ${ }^{24}$ Sentimental fiction neither unequivocally "affirms an embodied, affective personhood", nor does it derive all of its political force from its attempts to render "the feelings in the story ... tangibly present in the flesh of the reader". ${ }^{25}$ Instead, both the characters and the implied readers of sentimental fiction are ultimately modeled on a modern, enlightened notion of the subject as capable of counterbalancing feeling by reason. Sentimental literature is in line with Enlightenment thought not only in the sense that it pits, as Cathy N. Davidson and Jay Fliegelman already observed in the 1980s, female subjects' striving for liberty against the old, republican-patriarchal order. ${ }^{26}$ Sentimental literature is also enlightened in its anthropological outlook.

When the first sentimental American novels were published, Scottish common sense philosophy dominated academic philosophy in the U.S. and was widely disseminated in periodicals. ${ }^{27}$ Perry Miller goes as far as pronouncing Scottish philosophy "the official metaphysics of America" during the first half of the nineteenth century. ${ }^{28}$ As Gregg Camfield has shown, Scottish thinkers such as Hugh Blair and Archibald Alison greatly influenced Harriet Beecher Stowe when she wrote Uncle Tom's Cabin (1852), ultimately prompting her to opt for an "emotional antirationalism". ${ }^{29}$

While Camfield's reading of Uncle Tom's Cabin is as powerful as it is debatable, the earlier sentimental novels that I am concerned with most certainly do not throw reason to the wind. In insisting that feeling needs to be counterbalanced by reason, texts such as The Power of Sympathy, Charlotte Temple, The Coquette, and Emily Hamilton subscribe to a view of human nature that is, in

24 Joanne Dobson, “Reclaiming Sentimental Literature”, American Literature 69.2 (1997): 266.

25 Marianne Noble, “The Ecstasies of Sentimental Wounding in Uncle Tom's Cabin”, Yale Journal of Criticism 10.2 (1997): 295-320; and Karen Sánchez-Eppler, Touching Liberty: Abolition, Feminism, and the Politics of the Body (Berkeley: U of California P, 1993) 27.

26 See Davidson, Revolution and the Word; and Jay Fliegelman, Prodigals and Pilgrims: The American Revolution against Patriarchal Authority, 1750-1800 (Cambridge: Cambridge UP, 1982).

27 William Charvat, The Origins of American Critical Thought, 1810-1835 (New York: Russel, 1986) 34-35.

28 Perry Miller, American Thought from the Civil War to World War One (New York: Rinehart, 1954) ix.

29 Gregg Camfield, "The Moral Aesthetics of Sentimentality: A Missing Key to Uncle Tom's Cabin”, Nineteenth-Century Literature 43.3 (1988): 335. 
fact, closer to that which underlies a continental European thinker's major treatise on art than to Scottish common sense philosophers' understanding of 'man'. In his twenty-seven letters On the Aesthetic Education of Man (1795), the German dramatist, poet, and philosopher Friedrich Schiller develops an aesthetic theory that is based on an Enlightenment anthropology which tempers Immanuel Kant's ethical rigor by stressing that the moral law cannot be imposed on human beings against their inclination. ${ }^{30}$ As do sentimental writers, Schiller suggests that the morality of human behavior cannot be grounded solely in the demands of reason but must be supported by feelings and subjective dispositions. At the same time, Schiller does not agree with Scottish common sense philosophers that feeling is a safe guide to rational behavior. Instead, he speaks of the need to reconcile and balance reason and feeling. And this is precisely what we also find in sentimental sympathy control.

That the anthropology which informs late eighteenth- and early nineteenthcentury sentimental novels published in the United States is closer to that which underlies a continental European thinker's aesthetic theory than to that propounded by Scottish common sense philosophers - who, unlike Schiller, were widely read in the early republic ${ }^{31}$ - may come as less of a surprise if we consider the origin of 'aesthetics' in eighteenth-century German philosophy. When the term was first introduced in 1735 , it meant "the science of sensuous perception" or "the science of sensuous cognition". ${ }^{32}$ Coined and first defined

30 See Friedrich von Schiller, On the Aesthetic Education of Man, ed. and trans. Elizabeth M. Wilkinson \& L.A. Willoughby (Oxford: Clarendon P, 2005).

31 See Janice G. Schimmelmann, Books on Art in Early America (New Castle: Oak Knoll P, 2007).

32 See Alexander Gottlieb Baumgarten, Reflections on Poetry / Meditationes philosophicae de nonnullis ad poema pertinentibus, trans. Karl Aschenbrenner \& William B. Holther (Berkeley: U of California P, 1954) §116, 78; and Jeffrey Barnouw, "Feeling in Enlightenment Aesthetics", Studies in Eighteenth-Century Culture 18 (1988): 324. In Aesthetica, Baumgarten defines 'aesthetics' thus: "AESTHETICA (theoria liberalium artium, gnoseologia inferior, ars pulchre cogitandi, ars analogi rationis) est scientia cognitionis sensitivae”. A.G. Baumgarten, Ästhetik [Aesthetica], trans. Dagmar Mirbach, vol. 2. (Hildesheim; Felix Meiner, 2007) §1, 60. This is Jeffrey Barnouw's translation, which comes with useful glosses in square brackets: “Aesthetics, as the theory of the liberal arts, lower-level epistemology [gnoseologia inferior], the art of thinking finely [literally, beautifully, ars pulchre cogitandi], and the art of the analogy of reason [i.e., the associative or natural-sign-based capacity of empirical inference common to man and higher animals], is the science of sensuous cognition” (Barnouw 1988, 324). Note that Baumgarten here presents more than one definition, and that the definitions are not equivalent. It may safely be assumed that he used several of these more traditional descriptions mainly to gently introduce his readers to a new science. Once one strips the definition from these, a two-part core remains: aesthetics is the science of sensuous cognition and the art of thinking finely; see 
by Alexander Gottlieb Baumgarten in his M.A. Thesis Meditationes philosophicae de nonnullis ad poema pertinentibus (1735), and expanded on in his two-volume Aesthetica (1750/1758), the new 'science' of aesthetics quickly took hold in the German-speaking world. ${ }^{33}$ Immanuel Kant based his lectures on metaphysics on Baumgarten's Metaphysica (1739), which contains his earlier definition of aesthetics, draws on Baumgarten's theory of sensuous cognition in the second edition of his Critique of Pure Reason, and critically engages with him in his own aesthetic theory, Critique of the Power of Judgment (1790). ${ }^{34}$ Thus, from its beginnings, continental European aesthetics has centrally revolved around questions of aisthēsis (sensation, sense perception, feeling) - the very questions that are also at the heart of sentimental novels.

Writing against the background of a French Revolution that had devolved into terreur, Schiller considers the experience of freedom in the world of aesthetic semblance a necessary training that prepares human beings for the political freedom the Enlightenment project envisages: "[I]t is only through Beauty that man makes his way to Freedom". ${ }^{35}$ Contrary to Schiller, early American sentimental writers seem to have little faith in their readers' ability freely to channel their aesthetic experience in socially useful ways. As Emily Hamilton's, Charlotte Temple's, and Eliza Wharton's examples demonstrate, human beings are so prone to be swayed by their feelings that they need guidance in regulating their affective economy. Sentimental novelists resort to didacticism as one of the staple techniques of the subgenre to ensure that our sympathy attaches itself to the right characters. To give but one example: in the case of Charlotte Temple, the motherly narrator reminds us that the death of Mademoiselle La Rue - the novel's emotionally manipulative schoolmistress, who convinces Charlotte to elope with her seducer and thus precipitates Charlotte's ruin - is "a striking example that vice, however prosperous in the beginning, in the end leads only to misery and shame". ${ }^{36}$ Keenly aware of the power of emotional appeals - both by the novel itself and its villainous characters - Rowson's didacticism aims at enabling her readers to achieve a certain distance from a purely affective experience of the text, thus immunizing them against emotional manipulation and deception.

In Schiller's model of aesthetic education, any such determination of the reader's response interferes with the educational function of art. As a matter of

Karlheinz Barck, Dieter Kliche, \& Jörg Heininger, “Ästhetik/ästhetisch”, Ästhetische Grundbegriffe, ed. Karlheinz Barck et al, vol. 1 (Stuttgart: Metzler, 2000) 326.

33 See Baumgarten, Meditationes; and Aesthetica.

34 See Barck, Kliche, \& Heininger 2000, 324.

35 Schiller, Aesthetic Education, 9.

36 Rowson, Charlotte Temple, 120. 
fact, Schiller explicitly defines his notion of aesthetic education against didactic art: "Not less self-contradictory", Schiller writes, "is the notion of a fine art which teaches (didactic) or improves (moral); for nothing is more at variance with the concept of beauty than the notion of giving the psyche any definite bias". ${ }^{37}$ Schiller's strictures against didactic art resonate with Immanuel Kant's assertion that art allows for the free play of the faculties. ${ }^{38}$ Yet Schiller's aversion to didacticism is most firmly grounded in his anthropology. Schiller considers human beings to be possessed of a dual nature. Two drives are at war within us: the 'material' or 'sensuous drive' (Stofftrieb) makes us receptive to the demands of external reality and strives for ever new sensory input; the 'formal drive' or 'form-drive' (Formtrieb) seeks to impose order and give a shape to the world and the self. In its passivity, the sensuous drive is linked to sense, sensation, and feeling, while the formal drive is linked to reason, understanding, and the law. For Schiller, human beings are whole only if the two drives balance each other out, and he postulates a third drive, the play drive (Spieltrieb), that continually plays the other two drives off against one another:

Reason, on transcendental grounds, makes the following demand: Let there be a bond of union between the form-drive and the material drive; that is to say, let there be a playdrive, since only the union of reality with form, contingency with necessity, passivity with freedom, makes the concept of human nature complete. ${ }^{39}$

This play drive, Schiller adds, is activated in the presence of beauty in general and the fine arts in particular. Thus, it is in the experience of art that human beings may live the fullness of their existence:

[S]ince in the enjoyment of beauty, or aesthetic unity, an actual union and interchange between matter and form, passivity and activity, momentarily takes place, the compatibility of our two natures, the practicability of the infinite being realized in the finite, hence the possibility of sublimest humanity, is thereby actually proven. ${ }^{40}$

37 Schiller, Aesthetic Education, 157.

38 Schiller, Aesthetic Education, 102-04 et passim. According to Kant, Gilles Deleuze explains, aesthetic pleasure is based on " $a$ free and indeterminate accord between faculties. ... Indeed, the pleasure which we suppose to be communicable to, and valid for, everyone is nothing other than the result of this accord. Since it does not come into being under a determinate concept, the free play of imagination and understanding cannot be known intellectually, but only felt. ... We explain the universality of aesthetic pleasure or the communicability of higher feeling by the free accord of the faculties". Gilles Deleuze, Kant's Critical Philosophy, trans. Hugh Tomlinson \& Barbara Habberjam (Minneapolis: U of Minnesota P, 2003) 49-50; emphasis in original. 39 Schiller, Aesthetic Education, 103.

40 Schiller, Aesthetic Education, 189; emphasis in original. 
As do sentimental writers in their emotional appeals, Schiller seeks to temper the kind of ethical rigor Kant demands by stressing that the moral law cannot be imposed on human beings against their inclination; it must be grounded in their affective experience of the world. For Kant as for Schiller, human perfection is moral perfection and "beauty" is, in Kant's words, "the symbol of the morally good" in the sense that it allows us to become "aware of a certain ennoblement and elevation above the mere receptivity for a pleasure from sensible impressions, and also esteems the value of others in accordance with a similar maxim of their power of judgment". ${ }^{41}$ But Schiller adds that this human ideal can be reached only when "reason and the senses, duty and inclination, are in harmony". ${ }^{42}$ Thus, the freedom Schiller speaks of when, in his Kallias letters, he defines beauty as "freedom in appearance", ${ }^{43}$ is the free interplay of sensuousness and reason. In allowing for human beings' self-realization, aesthetic experience can pave the way to freedom since by balancing out the demands of the sensuous and the formal drive, of feeling and reason, it liberates us from being determined by either. Thus, it is aesthetic education that prepares individual human beings for the free society the Kantian Enlightenment promises, but in its appeal to only the rational nature of human beings cannot realize. ${ }^{44}$

While Schiller and sentimental American novelists both stress the moral productivity of emotions, they seem to draw up two very different maps of the relationships between art, its recipients, and the world. For Rowson and her fellow sentimental writers, literature educates its readers by way of emotional appeals and moral instruction. By way of contrast, Schiller's program of aesthetic education to human autonomy and freedom functions precisely in the absence of such determinations. Yet once we take a closer look at early sentimental novels, we discover that their anthropology as well as their models of aesthetic education are closer to Schiller's than appears at first sight.

41 Immanuel Kant, Critique of the Power of Judgment, trans. Paul Guyer \& Eric Matthews, The Cambridge Edition of the Works of Immanuel Kant, ed. Paul Guyer (Cambridge: Cambridge UP, 2000) §59, 227. See also Annemarie Gethmann-Siefert’s discussion of the links between Schiller's Aesthetic Education of Man and Kant's third critique; Annemarie Gethmann-Siefert, Einführung in die Ästhetik (Munich: Fink, 1995) 149-50.

42 Friedrich von Schiller, "On Grace and Dignity”, Aesthetic and Philosophical Essays (New York: P.F. Collier \& Son, 1902) 207.

43 Friedrich von Schiller, "Kallias oder über die Schönheit”, Kallias oder über die Schönheit. Über Anmut und Würde (Stuttgart: Reclam, 1971) 10; my translation.

44 My understanding of his anthropology and aesthetics is indebted to Antje Büssgen's admirably clear exposition of Schiller's reflections on human and artistic beauty in Glaubensverlust und Kunstautonomie: Über die ästhetische Erziehung des Menschen bei Friedrich Schiller und Gottfried Benn (Heidelberg: Winter, 2006) 54-135. 
Bringing late eighteenth- and early nineteenth-century American writers of sentimental fiction into a dialogue with contemporaneous European aestheticians such as Baumgarten and Schiller helps us understand the extent to which American writers' anxieties concerning the power of their work to either educate or lead astray and deceive its readers are more than defensive (or disingenuous) responses to the detractors of the novel, who disdained literature for its lack of moral or religious rectitude. ${ }^{45}$ These anxieties are real in the sense that they bear witness to more broadly based concerns about the reliability of sensuous perception that haunt early American novelists as much as they do early European aestheticians. For a thinker such as Baumgarten, to devote books to the study of sensuous cognition around 1750 is a daring project that still cannot quite shake off doubts concerning its own legitimacy. Baumgarten himself inherits the rationalist tradition via Gottfried Wilhelm Leibniz and Christian Wolff, and he situates himself within it when he asserts that sensory perception allows us to know things clearly but also confusedly (clara et confusa), i.e., without the conceptual distinctness of reason - which alone allows for cognition distinguished by "claritatis intensio per distinctionem" (clarity intensified by distinctness). ${ }^{46}$ Within Baumgarten's rationalist epistemology, only the conceptual apparatus of reason can give us access to the perfect distinctness of universal forms. Baumgarten's choice to accord the human senses their own place vis-àvis rational cognition must be appreciated with these doubts concerning the reliability of human perception in mind. ${ }^{47}$

Even in Schiller's On the Aesthetic Education of Man, which constitutes one of the most ringing defenses of art and the artistic imagination at the end of the century, we can still detect traces of the rationalist mistrust in the senses. While he celebrates the reconciliation of the receptive sensuous drive and the law-giving form-drive in the experience of art as a supreme expression of human freedom, he occasionally subordinates sensibility to reason when he insists that aesthetic experience serves a transitional function by leading human beings from sensuousness to rationality: "Our psyche passes, then, from sensation to thought via a middle disposition in which sense and reason are both active at the same time". ${ }^{48}$ In continental Europe at least, early aesthetics remains

45 See Charvat, The Origins of American Critical Thought; Paul C. Gutjahr, "No Longer Left Behind: Amazon.com, Reader-Response, and the Changing Fortunes of the Christian Novel in America”, Book History 5 (2002): 209-36; and Davidson, Revolution and the Word.

46 Baumgarten 2007, §617, II: 04.

47 See Barck, Kilche, \& Heininger 2000, 322-23; and Annemarie Gethmann-Siefert, Einführung in die Ästhetik (Munich: Fink, 1995) 44-50.

48 Schiller, Aesthetic Education, 141; emphasis in original. 
wedded to a belief in human rationality that tends to subordinate sensibility to reason. For early aestheticians, sensuous perception is both an indispensible and an imperfect guide to knowledge.

Both early European aestheticians and early American writers, then, valorize our sensual encounter of the world even as they register the fallibility of sensuous cognition. Just as our senses can always deceive us, art - which contains and mediates sensuous perception - can trick us. American novelists' suspicions that deception may not only be a relevant subject matter for their work but its very modus operandi becomes especially apparent in the case of sentimental fiction, whose power to move its readers revolves centrally around aisth$\bar{e}$ sis. If we focus on the senses in this sense - as corporeal, sensuous experience - we see that sentimental writers do not, as has been claimed by major theorists of sentimentalism, unconditionally affirm the expression of feelings. The link between continental European aesthetics and American sentimentalism is not as direct as Elizabeth Maddock Dillon suggests:

Aesthetics aims at producing feeling subjects who, insofar as they feel, are able to understand their own subjectivity as free - personal, unconditioned, and creative. It is the subjective feeling of freedom and personhood that eighteenth-century aesthetic theory links to the ideal of human freedom and the (putatively) universal rights of man that are central to liberal political theory. In related terms, sentimentalism links the capacity of individuals to feel deeply (often, to suffer) to an essential, shared humanity. ${ }^{49}$

Neither Kant's nor Schiller's aesthetics, which Dillon adduces as examples of her claims in the following paragraphs, "ai[m] at producing feeling subjects". Instead, they strive for and advocate a reconciliation of feeling and reason that has its analogue in sentimental sympathy control.

This take on the intertwinement of aesthetics and sentimentalism helps us explain why not only earlier texts such as Charlotte Temple and Foster's The Coquette but also later, supposedly proto-realist works such as Emily Hamilton firmly belong to the sentimental tradition. All of these novels testify to a major problem inherent in the affective economy of sentimentalism. For all of sentimentalism's claims to authenticity and truthfulness, the success of its emotional appeals does not depend on the veracity of the feelings that trigger processes of sympathetic identification. This problem - the problem that faked emotional distress can call forth heartfelt sympathy - haunts sentimentalism. Consider Charlotte Temple, which never affirms emotional expressiveness unequivocally. Instead, it negotiates a problem at the heart of sentimentalism. It is in line with early American novels' near-obsessive concerns about the ever-present possibi-

49 Elizabeth Maddock Dillon, “Sentimental Aesthetics”, American Literature 76.3 (2004): 500. 
lity of deception that Rowson's novel repeatedly warns its readers that feelings may be dissimulated. La Rue is the master dissimulator whose displays of emotion are repeatedly qualified as false and staged. When, returning with La Rue from a garden party that deeply offended Charlotte's sense of propriety, Charlotte suggests that the school's headmistress would have strongly disapproved of their presence at the party, La Rue paints the consequences of letting the headmistress know in the darkest colors:

“Nay, Miss”, said La Rue, "perhaps your mighty sense of propriety may lead you to tell her yourself. ... Perhaps it will give you pleasure”, continued she, letting fall some hypocritical tears, "to see me deprived of bread, and for an action which by the most rigid could only be esteemed an inadvertency, lose my place and character, and be driven again into the world, where I have already suffered all the evils attendant on poverty". ${ }^{50}$

While La Rue's fears concerning her position at the school may be entirely justified and sincere, her tears are qualified as "hypocritical" and thus fake. La Rue plays upon Charlotte's feelings and instrumentalizes the power of sympathy to further her own illicit ends. Such stratagems are a recurrent feature in early sentimental novels. In The Coquette, the rakish Major Sanford throws himself at Eliza Wharton's feet and gushes forth "a flood of tears" that is designed to divert his victim's affections away from the honorable (but boring) Reverend Boyer. ${ }^{51}$ In censuring the rakish Mr. Lambert, Emily Hamilton provides a proto-feminist perspective on seducers' artful manipulations of their victims' feelings: "[Y]our sex are constantly using the meanest artifices, to delude those whose youth or inexperience prevent them from perceiving the fatal snare which is laid for them, till they are entangled in it”. ${ }^{52}$

In Charlotte Temple, La Rue is successful because she "was touching Charlotte in the most vulnerable part" - her heart. ${ }^{53}$ Such scenes raise a crucial problem for novels whose whole affective economy and educational function seem based entirely on the possibility of sympathetic identification. If dissimulated feelings can provoke real emotional responses within fictional space, what guarantee is there that sentimental readers are not subjected to the same manipulation of their feelings? Sentimental novels repeatedly prove wrong one character's assertion in The Power of Sympathy that "[i]n the feelings of the heart there can be no dissimulation". ${ }^{54}$ Inadvertently, perhaps, sentimental writers evoke one of the major charges detractors of sentimental literature lay at its

50 Rowson, Charlotte Temple, 30.

51 Foster, The Coquette, 92.

52 Foster, The Coquette, 63.

53 Rowson, Charlotte Temple, 30.

54 Brown, The Power of Sympathy, 72. 
feet: that it deals in false emotions that manipulate its readers' feelings. For early American novelists, this presented an especially formidable challenge since they also had to contend with the powerful anti-fiction movement that was grounded in the Scottish common sense idea that truthfulness was a central human virtue. ${ }^{55}$

To perceive how Charlotte Temple negotiates that problem, we need to shift our attention away from its eponymous protagonist and toward one of the novel's minor characters. In Rowson's fictional world, it is Mrs. Beauchamp, Charlotte's benevolent and charitable friend, who serves as a model of ideal humanity. Unlike Charlotte, Mrs. Beauchamp is able to exert some form of control over her emotional life without suppressing her sensuous nature. The "most compassionate glance" Mrs. Beauchamp casts at Charlotte upon their first encounter already testifies to the latter. ${ }^{56}$ Yet while it is her compassion that sanctifies Mrs. Beauchamp, it is not her fellow feeling that distinguishes her from the other characters. It is the fact that her acts of kindness are based on conscious decisions rather than on irresistible calls from the heart. Thus, when she learns of Charlotte's distress, she does not immediately follow her inclination to call on her. Instead, she considers how her neighbors would judge her visit to the house of a fallen woman: "Dear sufferer", she says half to herself, half to Charlotte, "how gladly would I pour into your heart the balm of consolation, were it not for the fear of derision". ${ }^{57}$ Only once she discloses to her husband her desire to pay her distraught neighbor a visit and receives his approbation does Mrs. Beauchamp "resolve to brave even the scoffs of the world". ${ }^{8}$

At first sight, we might interpret Mrs. Beauchamp's delayed response to Charlotte's signals of distress as signs of her moral timidity and lack of autonomy. Yet this is clearly not the preferred reading. After all, by writing that Mrs. Beauchamp "resolve[d] to brave even the scoffs of the world" (my emphasis), Rowson stresses both the formidable power of public opinion Mrs. Beauchamp's plan comes up against and that, in the end, it was her decision, not her husband's, to put the plan into practice. Rather than letting her mind be ruled entirely by her heart, she considers the possible consequences of her actions, gets a second opinion, and only then makes an informed decision.

It is precisely that interposition of a moment of rational deliberation and consultation that sets Mrs. Beauchamp's actions apart from Charlotte's and prevents her from plunging headfirst into emotionally devastating situations. Con-

55 See Gutjahr, "No Longer Left Behind" and Davidson, Revolution and the Word.

56 Rowson, Charlotte Temple, 62.

57 Rowson, Charlotte Temple, 74.

58 Rowson, Charlotte Temple, 74. 
versely, Charlotte's fate is sealed by her inability to achieve any kind of distance from her affective experience. Charlotte is an easy prey for Montraville, La Rue, and Belcour because her sensuous nature is developed to such an extent that she remains an almost entirely passive recipient of the sensory data that keeps coming at her. As she writes in a letter to her mother, she has "a young heart glowing with sensibility". ${ }^{59}$ Unable to distinguish between being and appearance, artifice and honesty, she believes that the force of her own emotional response to Montraville's love letters or La Rue's protestations of friendship is sufficient proof of her antagonists' sincerity. Charlotte is all feeling and little reason and as such unable to exert rational control over her emotions. In her own words, she "never once reflected that the man who could stoop to seduction, would not hesitate to forsake the wretched object of his passion". ${ }^{60}$

So while Charlotte responds passively to others' appeals to her heart, Mrs. Beauchamp translates her sympathetic response to Charlotte's plight into rationally informed decisions. In this, she approaches Schiller's ideal human being whose freedom and autonomy is guaranteed by a harmonious interplay of feeling and reason. In early American novels, we frequently encounter such figures. In The Coquette, it is Rev. Boyer and Mrs. Richman - admittedly less attractive characters than Mrs. Beauchamp - who most closely resemble that ideal. As Boyer puts it in a letter to Eliza, "The regard which I felt for you was tender and animated, but it was not of that passionate kind which ends in death or despair. It was governed by reason, and had a nobler object in view, than mere sensual gratification". ${ }^{61}$ Yet in my reading of Charlotte Temple, Mrs. Beauchamp is more than a character in a novel, she is also the figure of the reader in the text. Her sensuous-rational response to Charlotte's fate provides a model for a reading of early sentimental novels that has little need of didactic guidance because its aesthetic experience does not exhaust itself in sympathetic identification. Such a reading is enlightened in the sense that our feeling and our reason are engaged in it in equal measure to ensure that we are not determined by either.

This returns us to the major problem registered by the affective economy of sentimentalism. If, as La Rue's example suggests, feelings can be dissimulated to manipulate others' emotional responses, how can we - as readers of sentimental novels - be sure that we are not manipulated in the same way? In other words, if sentimental novels thematize, as Davidson argues, "the necessity of informed choice" in matters of matrimony and sexuality, ${ }^{62}$ how can sentimental

59 Rowson, Charlotte Temple, 80.

60 Rowson, Charlotte Temple, 80.

61 Foster, The Coquette, 103.

62 Davidson 2003, 200. 
writers ensure that their primary readership - young, unmarried women like Charlotte - actually has a choice given that it is assaulted by the novels' powerful emotional appeals and didactic intent? From the perspective of Schiller's aesthetics, literary didacticism and appeals to the reader's emotions alone are unlikely to produce an enlightened citizenry that freely aligns its actions with the moral law.

My contention is that Mrs. Beauchamp functions as an aperture for an alternative reading of early sentimental novels that manages to disengage itself from the force of these texts' emotional appeals and didactic intents. Responding to these novels as Mrs. Beauchamp responds to Charlotte, readers may experience something of the autonomy and self-determination Enlightenment thinkers champion. Thus, readers of sentimental novels are educated in ways that immunizes them against emotional manipulation without recourse to the stock phrases of literary didacticism. Rowson's decision to name her model character Mrs. Beauchamp is therefore entirely appropriate. Its literal translation, 'beautiful field', aligns her not only with the countryside as the preferred space in the republican imagination; it aligns her also with the realm of beauty that the artistic imagination opens up. As we enter that realm, Schiller maintains, the pressures of the empirical world lose their hold over us so that we can experience the fullness of our humanity and, by extension, something of the freedom that the Enlightenment promises.

Sentimental sympathy control must be understood in this trans-Atlantic context, where American literary production in the early republic and early European theorizations of art meet. Reading a novel such as Emily Hamilton from this vantage point allows us to understand that Sukey Vickery's decision not to let her characters give full rein to their emotions does not testify, as Slawinski claims, to Emily Hamilton's realism, just as sympathy control in other sentimental novels such as The Power of Sympathy, The Coquette, and Charlotte Temple does not testify to these texts' realist aesthetic. Bringing together early European aesthetics and contemporaneous American literary production allows us to see that sympathy control is an integral part of a sentimental aesthetics that is grounded in an Enlightenment anthropology that radiates across the Atlantic. This anthropology does not valorize unrestrained emotionality; instead, it suggests that only the reconciliation of reason and feeling - a reconciliation that may well necessitate the concealment and even suppression of particularly powerful emotions - can pave the way to liberty. This may not be an especially appealing view of human nature, partly because it does not chime easily with the political force revisionist scholars attribute to sentimental emotions. But it is that which early sentimental novels ultimately advocate. 